\title{
ABORTIFACIENT EFFECTS OF VIBRIO CHOLERAE EXO-ENTEROTOXIN AND ENDOTOXIN IN MICE
}

\author{
GABRIEL J. GASIC, TATIANA B. GASIC AND JEROME F. STRAUSS, III \\ Departments of Pathology and Obstetrics and Gynecology, \\ University of Pennsylvania School of Medicine, Philadelphia, \\ Pennsylvania 19174, U.S.A.
}

(Received 13th Fanuary 1975)

\begin{abstract}
Summary. To study antifertility properties of microbial toxins, exoenterotoxin and endotoxin from Vibrio cholerae were injected intravenously into mice at different times during pregnancy. The two substances induced termination of pregnancy, but the patterns of abortifacient activity were different. Exotoxin terminated pregnancy in mice when administered between Days 4 and 10 of gestation, but abortifacient activity was reduced in animals more than 10 days pregnant; exogenous progesterone did not protect the pregnancies. Endotoxin was most effective in terminating pregnancy when injected after mid-gestation and the active principle was heat-stable; exogenous progesterone was not able to prevent the effects of endotoxin. Animals treated with endotoxin on Day 17 often gave birth to live young prematurely; indomethacin reduced the incidence of premature littering. The results demonstrate that exo- and endotoxins have antifertility properties and both appear to act on intrauterine targets rather than inducing progestin deficiency.
\end{abstract}

\section{INTRODUCTION}

Maternal bacterial and viral infections during pregnancy are associated with an increased incidence of fetal death, congenital malformations, placental abruption, premature rupture of membranes and pre-maturity (for review see Charles \& Finland, 1973). The factors responsible for these sequelae have not been elucidated. Since it is possible that substances released from the invading organisms cause these phenomena, we have undertaken a study of the effects of purified microbial toxins on pregnancy. In the present study, we examined the effects of administration of exo-enterotoxin and endotoxin from Vibrio cholerae to mice at different stages of gestation. Although $V$. cholerae are not common pathogens in obstetrical practice, their products were studied because of the availability of both exo- and endotoxin.

\section{MATERIALS AND METHODS}

Mice of the CF-1 strain (Carworth Farms, New York) were maintained in a controlled environment with $14 \mathrm{hr}$ light/10 hr darkness and were mated to 
males of proven fertility. The presence of a vaginal plug following evening mating was designated Day 1 of pregnancy.

Purified cholera exo-enterotoxin (exotoxin) and choleragenoid (lot 3/11/71), a protein which is immunologically identical to exotoxin but lacking biological activity, were isolated by the method of Finkelstein \& LoSpalluto (1970; see also LoSpalluto \& Finkelstein, 1972) and supplied by the National Institute of Allergy and Infectious Diseases; $40 \mathrm{ng}$ exotoxin are equivalent to $1 \mathrm{Craig} \mathrm{Lb}$ Unit (Craig, 1971).

Exotoxin and choleragenoid were dissolved in tris-EDTA buffer $(0.5 \mathrm{M}$-tris, $0.001 \mathrm{~m}-\mathrm{EDTA}, 0.003 \mathrm{M}-\mathrm{NaN}_{3}, 0.2 \mathrm{M}-\mathrm{NaCl}, \mathrm{pH} 7.5$ ) and were diluted with phosphate-buffered saline (PBS) before injection. In control experiments, exotoxin was inactivated by heating to $80^{\circ} \mathrm{C}$ for $30 \mathrm{~min}$.

A fraction containing endotoxin was generously supplied by $\operatorname{Dr} R$. A. Finkelstein, University of Texas Southwestern Medical School. This endotoxinrich material eluted as a leading peak of a Sephadex G-75 chromatography during purification of the exotoxin (Finkelstein \& LoSpalluto, 1970). The endotoxin fraction was dissolved in PBS and heated to $80^{\circ} \mathrm{C}$ for $30 \mathrm{~min}$ to inactivate contaminating exotoxin. All injections of exotoxin, choleragenoid and endotoxin were given into the tail vein in a volume of $0.25 \mathrm{ml}$.

Progesterone or progesterone and oestrone (Sigma Chemical Co.) were administered subcutaneously in sesame oil. Indomethacin (Merck, Sharp and Dohme) was suspended in a solution of $1 \%$ Emulphor EL-620 (G.A.F. Co.) in $0.9 \%$ saline and injected subcutaneously.

In some experiments, pregnant mice were killed at different intervals following treatment and examined for the condition of implantations; in others, they were killed after parturition and the young were counted and assessed for malformations and viability. In one study, mice were bilaterally ovariectomized through lumbar incisions under ether anaesthesia on Day 6 of pregnancy and then treated with $500 \mathrm{ng}$ of either exotoxin or denatured exotoxin on the day of surgery and also on Day 8 . Hormonal replacement therapy with either $2 \mathrm{mg}$ progesterone/day and a single dose of $0.5 \mu \mathrm{g}$ oestrone on the first treatment day, or a combination of $2 \mathrm{mg}$ progesterone and $0.5 \mu \mathrm{g}$ oestrone was begun $2 \mathrm{hr}$ before ovariectomies were performed and continued daily until mice were killed on Day 15.

\section{RESULTS}

Cholera exotoxin

Single injections of $1000 \mathrm{ng}$ exotoxin in the peri-implantation period prevented gestation in about $60 \%$ of mice, while pregnancy continued normally in the majority of animals receiving $1000 \mathrm{ng}$ heat-inactivated toxin (Table 1 ). The mean number of embryos in or young born to mice receiving exotoxin and remaining pregnant was similar to that observed in mice treated with inactivated toxin and there were no gross malformations observed in the conceptuses.

Administration of two $500 \mathrm{ng}$ injections $48 \mathrm{hr}$ apart resulted in almost total suppression of pregnancy when treatments were given between Days 4 and 10 of pregnancy (Table 1). When mice treated on Days 4 and 6 of gestation were 
killed within 5 days following the second exotoxin injection, the uteri contained the debris of resorbing implantations. When killed at later intervals, the only evidence of previous pregnancy was the presence of small mesometrial scars. Administration of exotoxin on Days 6 and 8 or Days 8 and 10 and autopsy 5 to 8 days after the last injection, resulted in haemorrhagic lesions in the placentae and fetal membranes, and subsequent total resorption of the conceptuses within a few days.

Table 1. Effect of cholera exo-enterotoxin and choleragenoid on pregnancy in mice

\begin{tabular}{|c|c|c|c|c|c|c|c|}
\hline \multirow[b]{2}{*}{ Group } & \multirow[b]{2}{*}{$\begin{array}{l}\text { Days of } \\
\text { treatment }\end{array}$} & \multirow[b]{2}{*}{$\begin{array}{c}\text { Dosel } \\
\text { injection } \\
(\text { ng })\end{array}$} & \multirow[b]{2}{*}{$\begin{array}{l}\text { Day of } \\
\text { autopsy }\end{array}$} & \multicolumn{2}{|c|}{ Denatured exotoxin } & \multicolumn{2}{|c|}{ Exotoxin } \\
\hline & & & & $\begin{array}{c}\text { No. of mice } \\
\text { pregnant/no. } \\
\text { treated }\end{array}$ & $\begin{array}{l}\text { No. of embryos/ } \\
\text { pregnant mouse }\end{array}$ & $\begin{array}{c}\text { No. of mice } \\
\text { pregnant/no. } \\
\text { treated }\end{array}$ & $\begin{array}{l}\text { No. of embryos } \\
\text { pregnant mouse }\end{array}$ \\
\hline 1 & 4 & 1000 & 20 & $10 / 10(100)$ & * & $4 / 11(36 \cdot 4)$ & * \\
\hline 2 & 5 & 1000 & 19 & $11 / 18(61 \cdot 1)$ & $12.5+0.7$ & $6 / 17(35 \cdot 3)$ & $11 \cdot 8+1 \cdot 3$ \\
\hline 3 & 4 and 6 & 500 & 18 & $15 / 17(88 \cdot 2)$ & $11 \cdot 4 \pm 0.8$ & $1 / 18(5 \cdot 6)$ & 11 \\
\hline 4 & 6 and 8 & 500 & 13 & $14 / 17(82 \cdot 4)$ & $12 \cdot 2 \pm 0.6$ & $1 / 18(5 \cdot 6)$ & 8 \\
\hline 5 & 8 and 10 & 500 & 18 & $\begin{array}{l}1 / 8(75 \cdot 0) \\
6 / 8\end{array}$ & $10.5+1.2$ & $0 / 9(0)$ & \\
\hline 6 & 12 & 1000 & 20 & $4 / 4(100)$ & & $8 / 8 \quad(100)$ & * \\
\hline 7 & 13 & 833 & 20 & $11 / 11(100)$ & * & $12 / 12(100)$ & * \\
\hline 8 & 13 & 1000 & 20 & $6 / 6(100)$ & * & $9 / 9(100)$ & * \\
\hline 9 & 14 & 1000 & 20 & $2 / 2 \quad(100)$ & * & $4 / 4 \quad(100)$ & * \\
\hline 10 & 14 and 16 & 660 & 20 & $11 / 11(100)$ & * & $12 / 12(100)$ & * \\
\hline 11 & 12 and 14 & 1000 & 19 & $6 / 7(85 \cdot 7)$ & $12 \cdot 0 \pm 0 \cdot 6$ & $9 / 17(52.9) \dagger$ & $8 \cdot 9 \pm 1 \cdot 3$ \\
\hline $12 \ddagger$ & 6 and 8 & 500 & 14 & & & $9 / 10(90)$ & $13 \cdot 1 \pm 0.5$ \\
\hline $13 \ddagger$ & 6 and 8 & 5000 & 14 & & & $4 / 4 \quad(100)$ & $12 \cdot 3 \pm 3 \cdot 0$ \\
\hline
\end{tabular}

Values are Means \pm S.E.M.; figures in parentheses are percentages.

* Six to fourteen live young/mouse.

$\uparrow$ Expulsion of conceptuses observed in some animals.

$\ddagger$ Choleragenoid.

Treatment of mice on or after Day 12 with doses of exotoxin which terminated early pregnancy did not result in disruption of gestation and the treated mice gave birth to healthy young (Table 1). Increasing the dose of exotoxin to two injections of $1000 \mathrm{ng}$ did cause termination of pregnancy in about half of the treated mice and a reduction in the number of viable conceptuses in other animals (Table 1). Some of the mice whose pregnancies were terminated apparently expelled the products of conception since no debris was present in utero at the time of autopsy. Choleragenoid displayed no abortifacient activity when administered in doses up to $5 \mu \mathrm{g}$ /injection (Table 1, Groups 12 and 13).

To determine whether exotoxin terminates pregnancy by inhibiting the secretion of ovarian hormones, we attempted to reverse the actions of exotoxin with exogenous progesterone or progesterone in combination with oestrone. In preliminary studies, daily administration of 2 to $4 \mathrm{mg}$ progesterone alone or in combination with $1 \mu \mathrm{g}$ oestrone did not prevent resorption of implantations in mice treated with $500 \mathrm{ng}$ exotoxin on Days 6 and 8 , but did delay the onset of resorption by several days. A more definitive study was then carried out with ovariectomized mice. All thirteen mice receiving progesterone and the exotoxin contained resorbing implantations when killed, but 8/11 mice receiving progesterone and the heat-inactivated toxin had apparently normal conceptuses 
$(9 \cdot 0 \pm 1 \cdot 4$, S.E.). The induction of embryo resorption by exotoxin in the progesterone-treated mice again progressed at a slower rate compared to that usually observed in mice given no hormonal supplement. Addition of oestrone to the hormonal therapy did not prevent the action of exotoxin in sixteen mice and the incidence of pregnancy (9/16) and survival of embryos $(5.6 \pm 1.4)$ was also reduced in control mice.

\section{Cholera endotoxin}

In contrast to the ng quantities of exotoxin required to terminate gestation, $\mu \mathrm{g}$ doses of the lipopolysaccharide fraction were needed to interfere with pregnancy and the active principle was heat stable. Mice tolerated the intravenous injection of $15 \mu \mathrm{g}$ endotoxin and this was used as the standard dose, the only significant side effect being diarrhoea.

Table 2. Effect of cholera endotoxin on pregnancy in mice

\begin{tabular}{|c|c|c|c|c|c|c|}
\hline \multirow[b]{2}{*}{ Group } & \multirow[b]{2}{*}{$\begin{array}{l}\text { Days of } \\
\text { treatment* }\end{array}$} & \multirow[b]{2}{*}{$\begin{array}{l}\text { Day of } \\
\text { autopsy }\end{array}$} & \multicolumn{2}{|c|}{$P B S$} & \multicolumn{2}{|c|}{ Endotoxin } \\
\hline & & & $\begin{array}{l}\text { No. of mice } \\
\text { pregnant/no. } \\
\quad \text { treated }\end{array}$ & $\begin{array}{l}\text { No. of embryos/ } \\
\text { pregnant mouse }\end{array}$ & $\begin{array}{l}\text { No. of mice } \\
\text { pregnant/no. } \\
\quad \text { treated }\end{array}$ & $\begin{array}{l}\text { No. of embryos/ } \\
\text { pregnant mouse }\end{array}$ \\
\hline $\begin{array}{l}1 \\
2 \\
3 \\
4 \\
5 \\
6 \\
7\end{array}$ & $\begin{array}{c}4 \\
5 \\
4 \text { and } 6 \\
6 \\
8 \\
12 \\
14\end{array}$ & $\begin{array}{l}18 \\
18 \\
10 \\
10 \\
14 \\
20 \\
19\end{array}$ & $\begin{array}{c}20 / 23(87 \cdot 0) \\
13 / 15(86 \cdot 7) \\
12 / 14(85 \cdot 7) \\
6 / 6 \quad(100) \\
11 / 13(84 \cdot 6) \\
8 / 8 \quad(100) \\
5 / 5 \quad(100)\end{array}$ & $\begin{array}{c}12 \cdot 8 \pm 0.4 \\
13 \cdot 8 \pm 0 \cdot 6 \\
11 \cdot 4 \pm 0.8 \\
13 \cdot 8 \pm 1 \cdot 0 \\
12 \cdot 3 \pm 0.7 \\
\ddagger \\
11 \cdot 4 \pm 1 \cdot 3\end{array}$ & $\begin{array}{l}23 / 30(76 \cdot 7) \\
6 / 15(40 \cdot 0) \\
3 / 19(15 \cdot 8) \\
1 / 12(8 \cdot 3) \\
6 / 16(37 \cdot 5) \\
0 / 12(0) \\
0 / 6 \quad(0)\end{array}$ & $\begin{array}{l}6 \cdot 0 \pm 1 \cdot 3 \\
11 \cdot 8 \pm 1 \cdot 0 \\
10 \cdot 0 \pm 1 \cdot 0 \\
15 \\
11 \cdot 7 \pm 1 \cdot 4\end{array}$ \\
\hline
\end{tabular}

Values are Means \pm S.E.M.; figures in parentheses are percentages.

* $15 \mu \mathrm{g}$ per injection.

$\uparrow$ Six to fourteen live young/mouse.

Administration of endotoxin on Day 4 of gestation did not result in significant inhibition of pregnancy, but the number of viable implantations at autopsy was approximately half the number found in mice receiving PBS (Table 2). In many of the mice treated with endotoxin on Day 4, the implantations were crowded in the uterus, unlike the uniform distribution in controls. There was some suppression of pregnancy in mice given endotoxin on Day 5, but the average number of implantations in animals remaining pregnant was nearly normal (Table 2). During the early post-implantation period (Days 6 to 8 ), administration of endotoxin terminated pregnancy in a significant number of mice, but endotoxin was most effective in ending pregnancy when injected on or after Day 12 when fetal death was observed in all mice receiving a single $15 \mu \mathrm{g}$ injection (Table 2).

In mice treated on Days 12 and 14, vaginal bleeding was observed within 24 $\mathrm{hr}$ and resorption of the conceptuses was advanced when mice were killed 48 to $96 \mathrm{hr}$ later. In many of these animals, intraperitoneal adhesions were observed at necropsy. Premature parturition was induced in one-half to twothirds of the mice receiving endotoxin on Day 17 of pregnancy. The apparently 
normal young were born approximately $36 \mathrm{hr}$ after endotoxin treatment (Table 3), but the offspring were neglected by their mothers and subsequently died. Animals that did not experience premature parturition were found to have resorbed their embryos.

To determine whether cholera endotoxin interferes with gestation by causing failure of the CL, progesterone was administered. Fourteen mice were treated with $4 \mathrm{mg}$ progesterone/day and fourteen with sesame oil on Days 12 to 14 beginning $2 \mathrm{hr}$ before $15 \mu \mathrm{g}$ endotoxin was administered on Day 12. None of the mice had viable implantations when killed on Day 15.

Table 3. Premature parturition induced by cholera endotoxin and its prevention by indomethacin

\begin{tabular}{|c|c|c|c|c|c|}
\hline Group & Treatment* & $\begin{array}{l}\text { No. of } \\
\text { mice }\end{array}$ & $\begin{array}{c}\text { No. of mice } \\
\text { resorbing } \\
\text { implantations } \\
(\%)\end{array}$ & $\begin{array}{c}\text { No. of mice } \\
\text { giving birth } \\
\text { prematurely } \dagger \\
(\%)\end{array}$ & $\begin{array}{c}\text { No. of mice } \\
\text { pregnant }(\%)\end{array}$ \\
\hline $\begin{array}{l}1 \\
2 \\
3\end{array}$ & \multirow{2}{*}{$\begin{array}{l}\text { PBS } \\
\text { Endotoxin } \\
\text { Endotoxin }+ \\
\text { vehicle } \\
\text { Endotoxin }+ \\
\text { indomethacin }\end{array}$} & $\begin{array}{r}8 \\
18 \\
11\end{array}$ & $\begin{array}{l}0 \\
5(27 \cdot 8) \\
5(45 \cdot 5)\end{array}$ & $\begin{array}{r}0 \\
12(66 \cdot 7) \\
6(54 \cdot 6)\end{array}$ & \multirow[t]{2}{*}{$\begin{array}{l}8(100) \\
1(5-6)\end{array}$} \\
\hline 4 & & 10 & $9(90.0)$ & $1(10.0)$ & \\
\hline
\end{tabular}

\footnotetext{
* Endotoxin (15 $\mu \mathrm{g}$ ) in PBS (phosphate-buffered saline) or PBS alone was administered on Day 17 of pregnancy and animals were killed on Day 19. Other mice received, in addition to endotoxin, $0.1 \mathrm{ml}$ of $1 \%$ Emulphor EL-620 in saline or $50 \mu \mathrm{g}$ indomethacin in the same vehicle twice daily on Days 17 and 18 with the first injection being given $2 \mathrm{hr}$ before the endotoxin was administered.

† In our laboratory, CF-1 mice begin to litter during the night of Day 19 and all animals have given birth by mid-morning of Day 20 .
}

The ability of indomethacin, an inhibitor of prostaglandin biosynthesis, to prevent the premature delivery and fetal death resulting from endotoxin treatment on Day 17 was tested. Mice received $50 \mu \mathrm{g}$ indomethacin or the vehicle twice daily on Days 17 and 18 were killed on Day 19 of pregnancy. The incidence of premature parturition was reduced to $10 \%$ in mice treated with indomethacin, but the conceptuses died and were resorbed (Table 3).

\section{DISGUSSION}

Cholera exotoxin is a protein which causes the acute diarrhoea of clinical cholera by altering the flow of salts and water in the intestinal lumen. The initial step in exotoxin action appears to be the stimulation of mucosal adenylate cyclase (Sharp, 1973), but the exotoxin is also capable of stimulating adenylate cyclase in a number of other tissues (see Cuatrecasas, 1973). If stimulation of adenylate cyclase is a requisite step in exotoxin action, the task of determining the specific site $(\mathrm{s})$ at which the exotoxin acts to interrupt pregnancy promises to be difficult since $3^{\prime}, 5^{\prime}$-cyclic adenosine monophosphate is a universal intracellular regulator of metabolism and cell proliferation.

The antifertility activity of the exotoxin is associated with the active protein 
since the ability to terminate pregnancy is lost upon heat denaturation, and choleragenoid, a biologically inactive protein which appears to be derived from the exotoxin molecule, does not display abortifacient activity. These doses are well below the $\mathrm{LD}_{50}$ which is $6500 \mathrm{ng}$ for $\mathrm{CF}-1$ mice weighing 21 to $25 \mathrm{~g}$ (R. S. Northrop, personal communication), but exotoxin administration did produce a marked increase in food and water consumption and increased urination and defaecation (Gasic \& Gasic, 1972). The exotoxin does not appear to cause ovarian failure because exogenous steroids (present study), LH, HCG and prolactin (unpublished observations) cannot protect pregnant mice against its action.

We currently believe that exotoxin acts by damaging the decidua, placenta, and/or embryos since the earliest signs of implantation degeneration are haemorrhagic lesions of the placentae and fetal membranes. The reduced effectiveness of the exotoxin when administered on or after Day 12 of pregnancy is of considerable interest since it is around Day 12 that the mouse placenta reaches morphological and functional maturity (Gardner \& Allen, 1942). It is possible that the mature placenta prevents the exotoxin from reaching the embryo. We do not have, at present, an explanation for the ability of exogenous progesterone to retard the action of exotoxin, although the supplemental progestin might hasten placental maturation and thus protect the conceptus.

The cholera endotoxin possesses antigestational activity which is most prominent when administered to mice during the last half of pregnancy. Endotoxin preparations from other organisms will also disrupt pregnancy and this action appears to be characteristic of microbial lipopolysaccharides (Zahl \& Bjerknes, 1943, 1944).

The mechanism by which bacterial endotoxins interfere with pregnancy has not been established, but from the present results and those of others (Chedid et al., 1962; Harper \& Skarnes, 1972) they do not appear to cause ovarian failure. Others have suggested that endotoxin damages the capillaries of the decidua and placenta. Injections of endotoxin directly into the embryos have no adverse effects upon pregnancy but haemorrhages in decidual and placental tissue result from endotoxin administration to the mother (Zahl \& Bjerknes, 1943; Rieder \& Thomas, 1960; McKay \& Wong, 1963; Parant \& Chedid, 1964). Haemorrhages may result from the release of vasoactive substances such as serotonin since treatment of pregnant mice with serotonin will cause placental haemorrhages and high doses of serotonin antagonists reputedly protect mice against the abortifacient actions of endotoxin (Parant \& Chedid, 1964).

It has recently been suggested that prostaglandins are involved in the mechanism of action of endotoxins because administration of abortifacient doses of Salmonella enteriditis endotoxin to pregnant mice causes a marked increase in plasma, uterine and urinary prostaglandin F content (Skarnes \& Harper, 1972; Harper \& Skarnes, 1972). Prostaglandin $F_{2 \alpha}$ will terminate pregnancy when administered to laboratory animals, domestic species and human and nonhuman primates and will also induce premature parturition when administered in late pregnancy (Labhsetwar, 1974). Our observations suggest that prostaglandins are probably not involved in the fetal death resulting from endotoxin treatment, since indomethacin did not prevent this action of endotoxin. 
However, the incidence of premature birth was reduced by indomethacin treatment, indicating that prostaglandins may mediate this effect. Essentially identical results were reported by Skarnes \& Harper (1972), although these authors later concluded that prostaglandins may also induce the fetal death resulting from toxin treatment (Harper \& Skarnes, 1972).

Although abortion has been observed in clinical cholera (Hirschhorn et al., 1969), it has not been attributed to the direct action of toxins on the reproductive system since the vibrios and their products are generally thought to be restricted to the intestinal lumen. However, our studies do illustrate that microbial products may play a significant role in pregnancy wastage. The abortifacient properties of bacterial lipopolysaccharides now seems well established but our observations clearly demonstrate that exotoxins have potent antigestational activity which is distinct from that of endotoxin. These findings should direct further attention to the role of soluble products of microorganisms in the pathogenesis of abnormal gestation.

\section{ACKNOWLEDGMENTS}

We thank Dr R. A. Finkelstein for providing cholera toxins and useful technical information. This work was supported by Grants M71.019G and M71.85C from the Population Council and Grant GB-19325 from the National Science Foundation, Program Project Grant NIH-HD-6274-03 and funds from the Lalor Foundation. One of us (J.F.S., III) is supported by NIGMS 5-T-05-GM02046-04.

\section{REFERENCES}

Charles, D. \& Finland, M. (1973) Obstetric and Perinatal Infections. Lea \& Febiger, Philadelphia.

Ghedid, L., Boyer, F. \& Parant, M. (1962) Etude de l'action abortive des endotoxines injectées à la souris gravide normal, castrée ou hypophysectomisée. Annls Inst. Pasteur 102, 77-84.

Craig, J. (1971) Cholera toxins. In Microbial Toxins, Vol. IIA, pp. 189-254. Eds S. Kadis, T. Montie and S. J. Ajl. Academic Press, New York.

Guatrecasas, P. (1973) Gangliosides and membrane receptors for cholera toxin. Biochemistry, N.Y. 12, $3558-3566$.

Finkelstein, R.A. \& LoSpalluto, J.J. (1970) Production, purification, and assay of cholera toxin. 7. infect. Dis. 121 (Suppl.), S63-S72.

GaRDNer, W.U. \& Allen, E. (1942) Effects of hypophysectomy at mid pregnancy in the mouse. Anat. Rec. 83, 75-91.

Gasic, G.J. \& GASIC, T.B. (1972) Effect of cholera exo-enterotoxin on reproductive performance in mice. Immun. Commun. 1, 223-238.

HARPER, M.J.K. \& SKarNes, R.C. (1972) Inhibition of abortion and fetal death produced by endotoxin or prostaglandin $\mathrm{F}_{2 \alpha}$. Prostaglandins 2, 295-309.

Hirschiorn, N., Ghowdhury, A.K.M.A. \& Lindenbaum, J. (1969) Cholera in pregnant women. Lancet i, $1230-1232$.

Labhsetwar, A.P. (1974) Prostaglandins and the reproductive cycle. Fedn Proc. Fedn Am. Socs exp. Biol. 33, 61-77.

LoSpalluto, J.J. \& Finkelstein, R.A. (1972) Chemical and physical properties of cholera exoenterotoxin and its spontaneously formed toxoid (choleragenoid). Biochim. biophys. Acta 257, 158166.

MaKAY, D.G. \& Wong, T.C. (1963) Effect of bacterial endotoxins on the placenta of the rat. Am. F. Path. 42, 357-372.

Parant, M. \& Chedid, L. (1964) Protective effect of chlorpromazine against endotoxin-induced abortion. Proc. Soc. exp. Biol. Med. 116, 906-909. 
RIEDER, R.F. \& Thomas, L. (1960) Studies of the mechanism involved in the production of abortion by endotoxin. F. Immun. 84, 189-193.

Sharp, G.W.G. (1973) Action of cholera toxin on fluid and electrolyte movement in the small intestine. A. Rev. Med. 24, 19-28.

SkARNEs, R.C. \& HARPER, M.J.K. (1972) Relationship between endotoxin-induced abortion and the synthesis of prostaglandin $F_{2 \alpha .}$. Prostaglandins 1, 191-203.

ZAHL, P.A. \& BJERKNES, G. (1943) Induction of decidua-placental hemorrhage in mice by the endotoxins of certain gram-negative bacteria. Proc. Soc. exp. Biol. Med. 54, 329-330.

ZAHL, P.A. \& BJERKNES, C. (1944) Effect of the endotoxin of Shigella paradysenteriae on pregnancy in rabbits. Proc. Soc. exp. Biol. Med. 56, 153-155. 